\title{
Superoxide dismutase and catalase: tissue activities and relation with age in the long-lived species Margaritifera margaritifera
}

\author{
CARLOS FERNÁNDEZ1 ${ }^{1}$ EDUARDO SAN MIGUEL ${ }^{1, \text { A }} \&$ \\ ALMUDENA FERNÁNDEZ-BRIERA ${ }^{2, \mathrm{~A}, \mathrm{~B}}$
}

\author{
${ }^{1}$ Department of Genetics, Faculty of Veterinary, University of Santiago de Compostela, Lugo, Spain \\ 2 Department of Biochemistry, Genetics and Immunology, Faculty of Biology, University of Vigo, Vigo, \\ Spain \\ A These authors contributed equally to this work
}

\begin{abstract}
Free radicals are extremely reactive and produce damage and modify cell functions. Furthermore, superoxide dismutase and catalase are believed to play a key role in the enzymatic defence of the cells. Indeed, some authors have argued that reduced free-radical damage could explain increased longevity. Margaritifera margaritifera is one of the longest-lived animals in the world (up to 100-200 years). Furthermore, this organism may serve as a useful model for gerontologists interested in exploring the mechanisms that promote long life and the slowing of senescence. The present study estimated for the first time individual enzymatic activity for superoxide dismutase isozymes ( $\mathrm{Cu}, \mathrm{Zn}-\mathrm{SOD}$ and $\mathrm{Mn}-\mathrm{SOD})$ and catalase in tissue preparations of gills, digestive glands and mantles of two natural populations of $M$. margaritifera. Superoxide dismutase activities showed significant differences in the tissues analysed of specimens from the same river and in specimens from different rivers for the same tissue. Catalase activity levels also showed significant variation, but differences among tissues, within tissues or between rivers were of relatively little interest. We failed to find any relationship between individual enzymatic activities and the age estimated for each mussel. Indeed, the wide variation found in activity levels can be principally interpreted as an adaptation to the unpredictable and changing nature of freshwater natural habitats.
\end{abstract}

Key terms: Margaritifera margaritifera, free radicals, aging, superoxide dismutase, catalase.

\section{INTRODUCTION}

Aging is made up of the progressive accumulation of changes with time. These changes are associated with higher probabilities of disease and death that are attributed to the aging process. Even nowadays, an understanding of the nature of aging continues to be a topic of considerable speculation. Both aging and senescence are under genetic control (besides environmental factors) and several genetic systems (gerontogenes) and/or their products, involved in these processes, have been nominated as good candidates (Curtsinger, et al. 1995; Rusting, 1998;
Delcourt, 1999); To name a few: superoxide dismutase and other antioxidants, pentose phosphate shunt, mitochondrial genes, multiples genes involved in cell proliferation (which provoke the Hayflick phenomenon), elongation factors (involved in protein synthesis), the telomerase, apoptosis, H-2 and HLA systems (with age-related immune functions and disease-related respectively), heat-shock proteins, regulatory changes (for instance, reduced transcription rates by globulins) and quantitative trait loci.

Free radicals (such as the superoxide anion) are chemical species containing one or more unpaired electrons $\left(\mathrm{O}_{2}+\mathrm{e}=\mathrm{O}_{2}{ }^{-}\right)$,

\footnotetext{
${ }^{B}$ Corresponding author: Dr. Almudena Fernández-Briera, Department of Biochemistry, Genetics and Immunology, Faculty of Biology, University of Vigo. ES-36310 Vigo (Spain) Tel.+34 986 812573, Fax +34 986 812556, E-mail abriera@uvigo.es
} 
and therefore are extremely reactive. Free radicals act on several cell components producing damage and modifying cell functions. The targets for these dangerous molecules are basically polyunsaturated fatty acids, some proteins and genetic material. Organisms continuously produce superoxide radicals $\left(\mathrm{O}_{2}^{-}\right)$as by-products of different metabolic pathways. Free radicals start a series of chain reactions and are sometimes transformed into other kinds of molecules. Yet most of them are destroyed in different ways by the antioxidant system, for example: vitamins $\mathrm{E}$ and $\mathrm{C}$ and antioxidant enzymes. Among the latter are notably superoxide dismutases (SOD), which are a group of metalloenzymes that catalyse the dismutation of the superoxide radical to hydrogen peroxide and $\mathrm{O}_{2}$. However, $\mathrm{H}_{2} \mathrm{O}_{2}$, in the presence of reduced transition metals $\left(\mathrm{Fe}^{2+}\right)$, can also be converted to the highly reactive hydroxyl radical $(\mathrm{OH} \cdot)$ by the Fenton reaction, although the catalase and gluthatione peroxidase systems can neutralise the hydrogen peroxide by converting it to $\mathrm{H}_{2} \mathrm{O}$ and $\mathrm{O}_{2}$.

SODs are generally classified into several types depending on their prosthetic metals, either $\mathrm{Mn}, \mathrm{Cu}$ plus $\mathrm{Zn}, \mathrm{Fe}$ or nickelcontaining superoxide dismutases (Fridovich, 1986), although hybrid SODs containing different combinations of those metals have also been found (Bannister et al., 1987; Barkley and Gregory, 1990).

The $\mathrm{Cu}, \mathrm{Zn}-\mathrm{SOD}$ isozyme is probably the most relevant antioxidant defence of the cell against oxygen toxicity, and it is well established that $\mathrm{Cu}, \mathrm{Zn}-\mathrm{SOD}$ is the irreplaceable enzyme for aerobic life (Peskin et al., 1977; Peskin, 1997). Aging is a natural process, in the course of which a wide variety of important changes take place in the metabolism of animal and plants. It has been reported that the activities of several enzymes decline with age, and if SOD exhibit a similar decline this can lead to a lowering of protection against superoxide-induced damage and a concomitant acceleration of age-dependent changes (Kellog and Fridovich, 1976), i.e., SOD activity may be a contributing cause of senescence. $\mathrm{Cu}, \mathrm{Zn}-\mathrm{SOD}$ has been related to the life-span and the metabolic rate in primate species (Tolmasoff et al., 1980; Cutler, 1983). In Drosophila, the biological effects of the absence of $\mathrm{Cu}, \mathrm{Zn}-\mathrm{SOD}$ have been reported, namely reduced viability, dramatically shortened life span, adult sensitivity to paraquat, low male and female fertility, etc (Parkes et al., 1998). Effects of reduced fertility and high mortality of embryos have been described in mice with a modified $\mathrm{Cu}, \mathrm{Zn}$-SOD gene ("knock-out females", Miller et al., 1993; Ho et al., 1998). In tumours, inhibition of the SOD activity leads to free radical-mediated damage to mitochondrial membranes and apoptosis (Huang et al., 2000). SOD and its involvement in plant senescence have been also indicated (Palma et al., 1993; Longa et al., 1994; Hernández-Nistal et al., 2002).

Just as Mn-SOD is located in the mitochondria, $\mathrm{Cu}, \mathrm{Zn}-\mathrm{SOD}$ is basically cytosolic, but both are coded by nuclear genes. Mn-SOD and its biological relevance (for instance, in relation to longevity) have been widely shown for different aerobic organisms (Majima et al., 1998; Wallace, 1999). On the other hand, the catalase (CAT), other antioxidant enzymatic defence, has several physiological functions in organelles and cytoplasm and plays an important part in cell adaptive responses (Aebi, 1995; Hunt et al., 1998). Indeed, it is of critical importance to minimize free radicals-induced damage to reduce the rate of aging, and some author argued quite strongly for their primacy as a mechanism of aging (Harman, 1957, 1962, 1981). Nevertheless, Rose (1991) has revised several evidences supporting or discarding the importance of free radicals, on the argument that reduced free-radical damage could explain increased longevity.

Most of the experiments relating to antioxidants and aging are based on strains or species raised in rather controlled environments (Rose, 1991; Finch, 1994). Natural populations have sometimes been used, but a major limitation of such studies is that the ages of wild adults cannot be determined (Curtsinger et al., 1995). Margaritifera margaritifera, the freshwater pearl shellfish, is one of the longest lived animals in the world (Ziuganov et al., 
1994): M. margaritifera has a life-span of between 100-200 years, depending on latitude and environmental conditions; the difference in maximum age (Amax) is 3-7 times when Southern populations, with Amax of 28-40 years, are compared to Northern Artic populations, with Amax of 114-190 years (Ziuganov et al., 1994). Moreover, a low genetic variability and significant high genetic differentiation is found in southern peripheral populations using microsatellite markers (Bouza et al., 2006). As occurs with other species of naiads, annual rings are present in the shell of this species, and thus it is possible to estimate ages (Bauer, 1992; Ziuganov et al., 1994; San Miguel et al., 2004) of individuals that have remained in natural conditions throughout their lives. Furthermore, freshwater pearl mussels may serve as a useful model for gerontologists interested in exploring the mechanisms that promote a long life and slow senescence: M. margaritifera with old shells show no sign of senescence, either in reproduction, ability to repair the shell or heal damaged tissues (Ziuganov et al., 2000). The present study aims to estimate and compare activity levels for SODs (Cu,Zn-SOD and Mn-SOD) and CAT in different tissues (gill, mantle and digestive gland) from specimens of this species collected into two drainages in Galicia (the Northwest of Spain). We also tried to find relationships between the age of the individuals and the enzymatic activity level for each tissue in order to find differences that might correlate with aging.

\section{MATERIAL AND METHODS}

\section{Materials}

Microbial NADH-diaphorase and superoxide dismutase were purchased from Roche Diagnostics GMBH (Mannheim, Germany). $\beta$-NADH, sulphanilamide and naphthylethylene diamine dihydrochloride were from Sigma (St. Louis, Mo., USA). Anthraquinone was supplied by Fluka Chemie AG (Buchs, Switzerland). All the other reagents used were of analytical grade.

\section{Biological specimens}

In the present work we have employed specimens of the unionoid mollusc Margaritifera margaritifera, that were manually collected from Masma and Eo Rivers (Galicia, Northwest Spain) between August and September in 1999. These rivers show the highest densities found in Galicia for this bivalve (personal observation). Since $M$. margaritifera is protected by European laws (listed in Annex V of the EC Habitats Directive), collection (40 individuals from each river) was always carried out under the supervision of forest rangers from the autonomous government (Xunta de Galicia).

Specimens dissection and treatment to obtain enzymatic tissue preparations

Freshly collected specimens of $M$. margaritifera (less than 24 hours) were dissected and gills, abductor muscles, foot, mantle and digestive gland were independently stored frozen at $-85^{\circ} \mathrm{C}$ until use.

To obtain enzymatic tissue preparations, all procedures were carried out at $0-4^{\circ} \mathrm{C}$ and tissues from the same specimen were always processed in parallel. As Eltsner et al. (1995) described, sample preparation is crucial for SOD activity determination. Therefore, the enzymatic samples were prepared from biological tissues as follows: 1) $0.20-1.50 \mathrm{~g}$ of tissue were minced and homogenized in 4 vols. of $0.2 \mathrm{M}$ phosphate buffer, $\mathrm{pH} 7.8,2 \mathrm{~min}$ at $1,000 \mathrm{rpm}$ in a ice bath in a Heidolph RGL 500 homogeniser; 2) the homogenate was sonicated under cooling, $3 \mathrm{~min}$ in a Branson 450 Sonifier at $45 \mathrm{~W}$ (to break the mitochondria); 3 ) the sonicated homogenate was centrifuged for $30 \mathrm{~min}$ at 20,000 g. Following Elstner et al. (1995) recommendations the obtained supernatant was divided in three aliquots: one was analysed immediately $\left(\mathrm{SOD}_{\text {total }}\right.$ and $\mathrm{CAT}_{\text {total }}$ determinations); another was analysed after exhaustive dialysis against 0.2 M phosphate buffer, $\mathrm{pH} 7.8$ (true SOD and CAT); and the third was subjected to heat denaturation by boiling for $6 \mathrm{~min}$ in a 
water bath and centrifugation for $30 \mathrm{~min}$ at 20,000 g (non-enzymatic SOD and CAT).

In all the enzymatic preparations, protein concentration was determined according to Lowry et al. (1951) using bovine serum albumin (BSA) as standard.

\section{Age determination of $M$. margaritifera specimens}

Determination of the age of the mussels was performed by counting the annuli in the shells. In order to make the annuli visible, the empty shells were placed $5 \mathrm{~min}$ into $\mathrm{KOH}(5 \%)$ at $50^{\circ} \mathrm{C}$, to remove the periostracum carefully; afterwards the shells were water-washed and dried. In very old specimens it is difficult to distinguish the last annuli (due to thinness and damaging) producing an imprecision in the age estimation up to $\pm 3 \%$ (Ziuganov et al. 1994). Consequently, the results are presented as a rough estimate of age. Nevertheless, this method has been recommended by different $M$. margaritifera specialised researchers (Bauer, 1992; Ziuganov et al., 1994, 2000; San Miguel et al., 2004) and it is suitable for age determination of freshwater pearl mussels up to 30-40 years.

\section{Antioxidant enzyme activities}

SOD assays

SOD (EC 1.15.1.1) activity was determined as previously described by Elstner et al. (1995). Briefly, the method is based on the generation of superoxide radicals by a microbial NADH-diaphorase and its detection by oxidation of hydroxylamine, yielding nitrite, which is quantified colorimetrically with sulphanilamide and naphthylethylene diamine. The dismutation of superoxide radicals by SOD inhibits the oxidation of hydroxylamine by these radicals in a concentration-dependent way. The effect of increasing amounts of SOD (or enzymatic preparation) on nitrite formation is measured.

For catalytic activity calculations, a SOD reference curve is made employing at least six concentrations of commercially available SOD. Furthermore, the activity of any sample can be estimated by relating the amount of protein that causes an inhibition of $50 \%$ in colour formation. One SOD enzyme unit is defined as the amount of protein that produces a $50 \%$ inhibition of the nitrite formation under the assay conditions. In this work, the SOD specific activity is expressed as SOD units by $\mathrm{mg}$ of enzymatic protein.

To determinate the Mn-SOD isoenzyme activity assays were performed in the presence of $1.5 \mathrm{mM}$ potassium cyanide (cyanide insensitive SOD). Cyanide sensitive SOD activity ( $\mathrm{Cu}, \mathrm{Zn}$-SOD isoenzyme) was calculated as the difference of activity in the absence and presence of cyanide in the assay for the same enzymatic preparation.

\section{CAT assay}

CAT (EC 1.11.1.6) activity was measured according to Clairbone (1985). The method is based in the direct measurement of the decrease in absorbance at $240 \mathrm{~nm}\left(\varepsilon_{240 \mathrm{~nm}}=\right.$ $43.6 \mathrm{M}^{-1} \mathrm{~cm}^{-1}$ ) due to $\mathrm{H}_{2} \mathrm{O}_{2}$ consumption by CAT. To optimise the assay conditions, relatively low $\mathrm{H}_{2} \mathrm{O}_{2}$ concentration was used. Assays were carried out in $50 \mathrm{mM} \mathrm{K}$ phosphate buffer, pH 7.0, with $10 \mathrm{mM}$ $\mathrm{H}_{2} \mathrm{O}_{2}$ at $25^{\circ} \mathrm{C}$.

In this work, CAT specific activity was expressed as units of CAT by mg of protein of enzymatic preparation. One CAT unit was defined as the mmol of $\mathrm{H}_{2} \mathrm{O}_{2}$ consumed per min.

\section{Statistical analysis}

Statistical analyses were performed using the JMP (v. 3.2, SAS Institute Inc. 1999) programme. Non-parametric tests (Wilcoxon/Kruskall-Wallis) were employed to detect differences among enzymatic activity levels. To find out whether two specific samples (when comparing more than two samples) showed significant differences, we applied a multiple comparison test for medians described by LeBlanc (2004). This test for medians used here is analogous to the Tukey's HSD test for means. Possible relationships between 
the age of the specimens and the enzymatic activity levels were analysed by linear regression.

RESULTS

\section{Enzymatic tissue preparations}

Three different enzymatic tissue preparations were used in this work: 1) freshly obtained tissue preparation (for total-SOD and total-CAT activities), 2) dialyzed enzymatic preparation (for true SOD and CAT activities) and 3 ) heatdenatured preparation (for non-enzymatic SOD and CAT activities) (see Materials and Methods).

We have not detected substances of low molecular weight that would interfere with enzymatic determinations: SOD and CAT activities were similar before and after the dialysis process (data not shown). Furthermore, we have not detected substances that would mimic the SOD and CAT activities because denatured enzymatic tissue preparations (for SOD) or inhibited by KCN (for CAT) showed null or very low values (data not shown). Therefore, the results presented in this article were obtained using the original and non-treated tissue preparations obtained as described in Materials and Methods.
Comparison of superoxide dismutase specific activity levels among tissues and between rivers

The specific activities (SOD units by mg of enzymatic protein for total-SOD, Mn-SOD as well as CuZn-SOD) were assessed in gill, digestive gland and mantle for every specimen from two different sample populations of freshwater pearl mussels coming from two drainages (rivers Eo and Masma, Northwest Spain). Cu,Zn-SOD activity was estimated by the SOD activity inhibited by $\mathrm{KCN}$ from values obtained for Mn-SOD and total-SOD (see Materials and Methods).

In the table I (River Eo) mean values corresponding to the total-SOD, Cu, ZnSOD and Mn-SOD activities are shown. These values were computed from the original supernatant for three tissues. Mantle exhibited the highest value for totalSOD activity (its activity, considering mean values, was 1.91 and 3.26 times higher than the one in gill and digestive gland, respectively). A Kruskall-Wallis test was applied for comparing differences among tissues $(\mathrm{H}=40.93, p<0.00)$. Furthermore, by using a multiple comparisons test for medians (LeBlanc 2004) significant differences $(p<0.05)$ were found between any pair of tissues (mantle-gill, mantledigestive gland and gill-digestive gland).

Specific activity levels for total-SOD, Mn-SOD and $\mathrm{Cu}, \mathrm{Zn}-\mathrm{SOD}$ obtained from gill, digestive gland (hepatopancreas) and mantle of the freshwater pearl mussel (Margaritifera margaritifera) in the river Eo. Results are expressed as SOD units by mg of enzymatic protein and are represented as mean values $(\mathrm{X}) \pm$ standard error $(\mathrm{SE})$ and medians $(\mathrm{M}) ; n$, number of individuals; $\mathrm{R}$, range.

\begin{tabular}{|c|c|c|c|c|c|c|c|c|c|c|c|c|}
\hline \multirow[b]{3}{*}{ ACTIVITY } & \multicolumn{11}{|c|}{ TISSUE } & \\
\hline & \multicolumn{4}{|c|}{ GILL } & \multicolumn{4}{|c|}{ DIGESTIVE GLAND } & \multicolumn{4}{|c|}{ MANTLE } \\
\hline & $\mathrm{X} \pm \mathrm{SE}$ & $(n)$ & $\mathrm{R}$ & M & $\mathrm{X} \pm \mathrm{SE}$ & $(n)$ & $\mathrm{R}$ & M & $\mathrm{X} \pm \mathrm{SE}$ & $(n)$ & $\mathrm{R}$ & M \\
\hline TOTAL SOD & $14.15 \pm 1.14$ & $(30)$ & $29.41-5.32$ & 13.16 & $8.29 \pm 1.08$ & $(28)$ & $33.33-2.96$ & 7.00 & $27.04 \pm 2.72$ & (29) & $55.55-6.13$ & 25.64 \\
\hline Mn-SOD & $5.95 \pm 0.84$ & (30) & $22.20-2.10$ & 4.24 & $5.44 \pm 0.78$ & $(26)$ & $19.23-1.77$ & 4.21 & $16.51 \pm 2.81$ & $(26)$ & $55.56-3.28$ & 11.85 \\
\hline $\mathrm{Cu}, \mathrm{Zn}-\mathrm{SOD}$ & $9.61 \pm 1.18$ & (23) & $25.02-2.81$ & 7.90 & $3.54 \pm 0.63$ & $(23)$ & $14.10-0.00$ & 2.75 & $14.71 \pm 1.80$ & (20) & $38.14-2.35$ & 13.64 \\
\hline
\end{tabular}


With respect to Mn-SOD specific activity in these tissues, mean values were slightly different to those obtained for totalSOD. Mantle showed the highest value (2.77 and 3.03 times higher than in gill and digestive gland, respectively). The Kruskall-Wallis test revealed important differences $(\mathrm{H}=24.89, p<0.00)$. However, the multiple comparisons test for medians detected that values from gill and digestive gland did not show relevant differences; for any other pair of comparisons, significant differences were always found $(p<0.05)$.

A visual inspection of $\mathrm{Cu}, \mathrm{Zn}-\mathrm{SOD}$ activity mean values (table I) reveals a similar performance to the total-SOD activity: again, the highest average was found in the mantle (approximately 0.65 and 5.00 times higher than that in gill and digestive gland, respectively). Activity for gill was 2.71 times higher than in the digestive gland. Both Kruskall-Wallis test $(\mathrm{H}=33.16, p<0.00)$ and comparisons for pair of medians $(p<0.05$ for any pair of tissues) indicated strong contrasts in enzymatic activity.

Specific activity levels for the two isozymes also showed variation within the same tissue. Thus, in gill $\mathrm{Cu}, \mathrm{Zn}-\mathrm{SOD}$ specific activity was 1.61 times higher than that found for Mn-SOD, whereas in digestive gland Mn-SOD activity was 1.54 times higher than the activity of the other isozyme $\quad(p<0.05$ by chi-squared approximation, in both cases applying the
Wilcoxon rank sum test). Values obtained from the mantle were very similar $(p=0.59)$.

Table II shows mean values and medians for different SOD activities in the Masma River as obtained from the original supernatants. As occurred in the Eo River, relevant variations also appeared following a similar trend. Total-SOD specific activities in gill and mantle were very likeness and 1.75 times higher than in the digestive gland. Only the comparison between gills and the digestive gland was significant $(p<0.05)$.

Mn-SOD specific activity (mean values and medians) was very similar for all tissues; on the contrary, Cu, Zn-SOD activity showed relevant contrasts. Thus, the digestive gland and mantle and/or gill exhibited the lowest and highest values respectively (2.70 times higher in mantle than in the digestive gland). The KruskallWallis test revealed significant differences among tissues $(\mathrm{H}=9.73 ; p<0.01)$ and the test for multiple comparisons indicated that medians for gill and mantle clearly differed from the one for the digestive gland $(p<0.05$, in both cases $)$.

One important difference was found in comparisons for intra-tissue activities as far as both isozymes are concerned: in gill, $\mathrm{Cu}, \mathrm{Zn}-\mathrm{SOD}$ activity was 1.76 times higher than Mn-SOD activity $(p=0.03)$. In mantle this same ratio reached a value of 1.66 , but it was not significant $(p=0.23)$ (table II).

Specific activity levels for total-SOD, Mn-SOD and $\mathrm{Cu}, \mathrm{Zn}-\mathrm{SOD}$ obtained from gill, digestive gland (hepatopancreas) and mantle of the freshwater pearl mussel (Margaritifera margaritifera) in the river Masma. Results are expressed as SOD units by mg of enzymatic protein and are represented as mean values $(\mathrm{X}) \pm$ standard error (SE) and medians $(\mathrm{M}) ; n$, number of individuals; $\mathrm{R}$, range.

\begin{tabular}{|c|c|c|c|c|c|c|c|c|c|c|c|c|}
\hline \multirow[b]{3}{*}{ ACTIVITY } & \multicolumn{12}{|c|}{ TISSUE } \\
\hline & \multicolumn{4}{|c|}{ GILL } & \multicolumn{4}{|c|}{ DIGESTIVE GLAND } & \multicolumn{4}{|c|}{ MANTLE } \\
\hline & $\mathrm{X} \pm \mathrm{SE}$ & $(n)$ & $\mathrm{R}$ & M & $\mathrm{X} \pm \mathrm{SE}$ & $(n)$ & $R$ & M & $\mathrm{X} \pm \mathrm{SE}$ & $(n)$ & $\mathrm{R}$ & M \\
\hline TOTAL SOD & $17.87 \pm 2.96$ & (21) & $62.5-6.10$ & 13.70 & $10.19 \pm 0.85$ & (19) & $17.24-2.04$ & 10.75 & $17.87 \pm 3.10$ & (21) & $55.56-2.43$ & 13.89 \\
\hline Mn-SOD & $6.73 \pm 1.03$ & (21) & $17.86-1.54$ & 5.32 & $5.43 \pm 0.59$ & (18) & $10.87-1.21$ & 5.76 & $7.50 \pm 1.15$ & (20) & $18.52-1.74$ & 5.33 \\
\hline Cu,Zn-SOD & $11.84 \pm 2.40$ & (20) & $46.20-1.95$ & 8.23 & $4.72 \pm 0.58$ & (18) & $8.76-0.46$ & 5.22 & $12.50 \pm 2.61$ & (19) & $39.93-1.98$ & 9.39 \\
\hline
\end{tabular}


On the other hand, comparisons of SOD levels within the same tissue between rivers (Wilcoxon's test) were also assessed (figure 1). Some relevant results were detected for total-SOD: the activity level was higher in the Masma sample than in the Eo sample for the digestive gland, whereas, on the contrary, for the mantle the activity level was higher in the Eo River (figure 1A); for Mn-SOD, only the comparison for the mantle was significant, the activity level being higher in the Eo sample $(p=0.00)$ (figure 1B); however, Cu,Zn-SOD levels were very similar between rivers for all tissues (figure 1C).

Comparison of catalase specific activity levels among tissues and between rivers

Catalase specific activity levels (CAT units by $\mathrm{mg}$ of protein of enzymatic preparation) were also measured from original supernatant solutions and in two samples of the rivers Eo and Masma respectively (see table III). Levels of catalase were assessed in extracts of gill, digestive gland and mantle. As for the SOD activity, levels for CAT showed a great variation within each tissue for each river. Minimum and maximum values varied between 0.92 and 82.10 , respectively, in tissues from specimens of the Eo River; whereas in the Masma River these values varied between 1.85 and 70.42 , respectively. Gill and mantle exhibited the highest values in both rivers, although the non-parametric test (Kruskall-Wallis test) did not detect significant differences for any river $(p=0.44$ and $p=0.75$, in the rivers Eo and Masma, respectively). On the other hand, no comparison between rivers for each tissue detected significant differences.
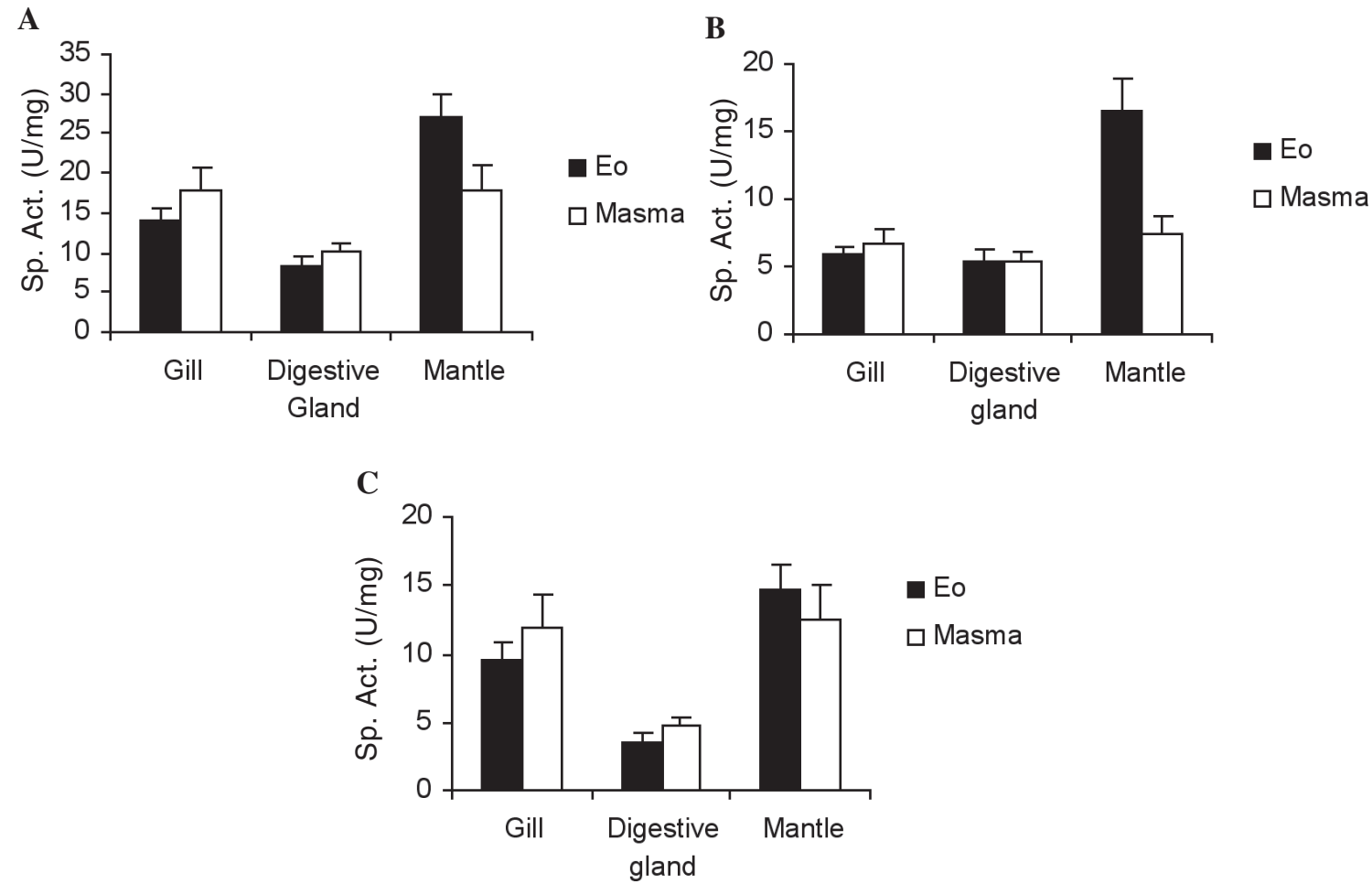

Figure 1: Specific activity of total-SOD (A), Mn-SOD (B) and Cu, Zn-SOD (C) in gill, digestive gland and mantle of Margaritifera margaritifera in the Eo and Masma Rivers. The assays were performed as described in Material and Methods. The results are expressed as specific activity (Sp. Act., Units of SOD/mg protein) and represent the means \pm standard error (SE) of 19-30 independent and duplicate assays performed for every tissue. ${ }^{*} p<0.05$ between Eo and Masma populations. 
Superoxide dismutase and catalase activities in relation to age

We tried to find out whether there was any relationship between the individuals' enzymatic activity and the age estimated for each mussel by counting the yearly annuli. Functions such as linear, quadratic, logarithmic, cubic and others, were tested for total-SOD, Mn-SOD, Cu,Zn-SOD and CAT from gill, digestive gland and mantle in the Eo and Masma samples. No one solid age-related change was detected. That is, activities for these enzymes did not change with age in a forecasting way for any tissue or sample. Resulting representative graphs for total-SOD and CAT levels from the mantle are displayed in figures $2 \mathrm{~A}$ and $2 \mathrm{~B}$ (rivers Eo and Masma, respectively).

\section{DISCUSSION}

The concept that free radicals are involved in the aging process was applied to the fact that the rate of aging, as measured by the $\log$ of the mortality, increase with advancing age; in multicellular organisms the process of aging could be going on at different rates in different tissues and organs so that death of the organism could occur because of impaired function of one part (organ or tissue), even though the other cells of the organism were capable of functioning satisfactorily (Harman, 1962). There are experimental evidences supporting this from many years ago, both in laboratory mice (Kellog and Fridovich, 1976) and humans and fruit flies (Parkes et al. 1998; Rusting 1998). Furthermore, SOD and CAT are believed to play a key role in the enzymatic defence of the cells against oxygen toxicity, this belief being substantiated by the ubiquitous presence of these enzymes in aerobic organisms (Peskin et al., 1977; Longa et al., 1994; García Martínez et al., 1995; Peskin, 1997; Delcourt, 1999; Hernández-Nistal et al., 2002).

In the present work, we showed SOD and CAT activities as estimated in the original (not treated) tissue preparations because we have not detected substances that could mimic these activities or lowmolecular weight substances interfering with the assays.

A major limitation on studies about natural populations (both in multicellular plants and in animals) is that the ages of adults cannot be reliably determined. Thus, estimations of enzymatic activity or other parameters can lead to difficult interpretations in relation to aging. In this work, $\mathrm{Cu}, \mathrm{Zn}-\mathrm{SOD}, \mathrm{Mn}-\mathrm{SOD}$ and CAT were identified in three organs: gill, mantle and digestive gland (hepatopancreas). The individual enzymatic activity for SOD and CAT was estimated for the first time in a natural population of the long-lived naiad M. margaritifera. As in other unionoids counting the yearly annuli on the shell permits estimating the age of each mussel. Individual ages varied considerably, having values between 14 and 44 (Eo River) or

TABLE III

Specific activity levels for catalase (CAT) obtained from gill, digestive gland (hepatopancreas) and mantle of the freshwater pearl mussel (Margaritifera margaritifera)

in the rivers Eo and Masma. Results are expressed as CAT units by mg of enzymatic protein and are given as mean values $(\mathrm{X}) \pm$ standard error $(\mathrm{SE})$ and medians $(\mathrm{M})$ of assays performed by duplicate for $n$ individuals; $\mathrm{R}$, range.

\begin{tabular}{|c|c|c|c|c|c|c|c|c|c|c|c|c|}
\hline & \multicolumn{12}{|c|}{ TISSUE } \\
\hline & \multicolumn{4}{|c|}{ GILL } & \multicolumn{4}{|c|}{ DIGESTIVE GLAND } & \multicolumn{4}{|c|}{ MANTLE } \\
\hline & $\mathrm{X} \pm \mathrm{SE}$ & $(n)$ & $\mathrm{R}$ & M & $\mathrm{X} \pm \mathrm{SE}$ & $(n)$ & $\mathrm{R}$ & $\mathrm{M}$ & $\mathrm{X} \pm \mathrm{SE}$ & $(n)$ & $\mathrm{R}$ & $\mathrm{M}$ \\
\hline RIVER E0 & $11.42 \pm 3.38$ & (24) & $82.10-2.09$ & 5.55 & $10.51 \pm 2.24$ & (24) & $44.90-1.08$ & 5.33 & $10.36 \pm 1.42$ & (24) & 29.90-0.9 & 29.01 \\
\hline RIVER MASMA & $18.78 \pm 4.37$ & (19) & $70.42-2.00$ & 12.63 & $10.79 \pm 1.44$ & (19) & $21.35-2.46$ & 10.89 & $11.59 \pm 1.65$ & (19) & $21.26-1.85$ & 12.84 \\
\hline
\end{tabular}


between 21 and 45 years (Masma River). That means, only adult mussels were analysed in this study, and the individuals called juveniles (6 years or less) were not detected because the sampling method applied: Juveniles remain deeply buried at the bottom of the river and a special effort is necessary to collect them (San Miguel et al., 2004). Even so, the enzymatic activity for SOD and CAT showed very extreme values in both samples (for example, in the Eo River sample $\mathrm{Cu}, \mathrm{Zn}$-SOD activity was estimated 0.00 in the digestive gland and while Mn-SOD was around 56 in the mantle; in the Masma River, sample totalSOD in gill reached maximum and
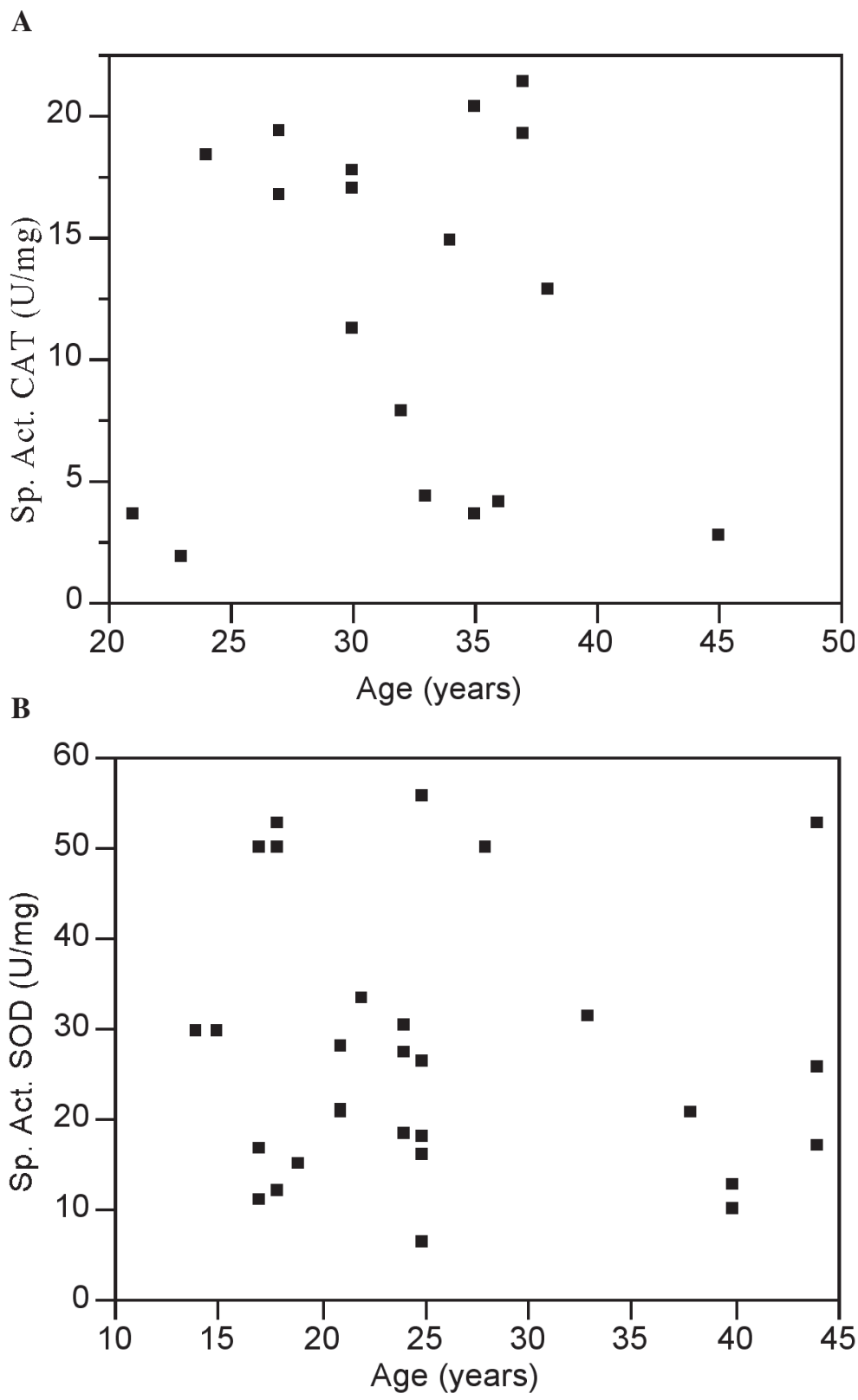

Figure 2: Catalase (CAT) activity from the mantle of Margaritifera margaritifera in the Masma River (A) and total superoxide dismutase (SOD) activity from the mantle of the same species in the Eo River (B) plotted against individual age. 
minimum values about 63 and 6 respectively). In spite of this strong variation, statistically relevant differences among tissues appeared in both samples, and the isozymes from gill and mantle always exhibited the highest activities. Even within tissues, it was possible to detect that the $\mathrm{Cu}, \mathrm{Zn}$-SOD activity level in gill was higher than the Mn-SOD in the same location for both samples. On the other hand, the Mn-SOD level from the mantle was markedly higher in the Eo sample than in the Masma sample.

CAT activity levels showed also large variation, but differences among tissues, within tissues or between rivers were of relatively little interest.

Important variations among organs or tissues are usual as far as its specific enzymatic activity is concerned. Variation among tissues in the SOD and/or CAT levels has been reported in rats (Kellog and Fridovich, 1976) by comparing brain, heart, kidney, liver, lung and spleen; in primates (Tolmasoff et al., 1980) in liver, brain, heart, and also in marine molluscs in gill and digestive gland (García Martínez et al., 1995; Viarengo et al., 1995).

In this way, the comparison of specific activities of antioxidant enzyme indicates that CAT activities are generally similar in vertebrates and invertebrates (163-1690 and 139-740 U/mg prot, respectively). In contrast, SOD activities are one order of magnitude lower in invertebrate (4-405 and 97-101 U/mg prot, respectively) (Livingstone et al., 1992).

The highest activities of the antioxidant enzymes in the digestive gland were detected in the common marine mussel Mytilus edulis (Livingston et al., 1992). However, we found lower activities in that tissue than in gill and mantle. Gamble et al. (1995) found that the SOD levels in Mytilus edulis were two times greater than in Pecten maximus, and the CAT levels were six times lower in the mussel. However, these results are hardly comparable with our data, because they are expressed in different units.

In this work we use similar methods to those of Winston et al. (1990), so the comparison is partially possible. Thus, the
SOD levels in the digestive gland of the short-lived marine bivalve Mytilus edulis are of a similar order to those shown by the long-lived $M$. margaritifera (10 vs. 20 $\mathrm{U} / \mathrm{mg}$ prot), and the CAT levels were lower in $M$. margaritifera (10 vs $70 \mathrm{U} / \mathrm{mg}$ prot). Although the activity of these enzymes in $M$. margaritifera slightly increases with age, we cannot find a correlation between CAT and SOD activity in respect to age.

Furthermore, several authors have tried to establish a relationship between SOD and/or CAT activity and age in animals grown in controlled environments. Thus, age-1 mutants of Caenorhabditis elegans yield more $\mathrm{Cu}, \mathrm{Zn}-\mathrm{SOD}$ and CAT than wild strains, and they are more long-lived (Larsen, 1993; Vanfleteren, 1993). Synthetic agents such as EUK-8 and EUK134, which simulate SOD and CAT activities, increase longevity in $C$. elegans (Melov et al., 2000). Similar results have been obtained in Drosophila: $\mathrm{Cu}, \mathrm{Zn}-\mathrm{SOD}$ over-expression increases life span (Sun and Tower, 1999); transgenic flies with extra genes for SOD and CAT increased their activity levels and showed a higher longevity (Orr and Sohal, 1994). In mice, Kellog and Fridovich (1976) compared short-lived and long-lived stocks at 9 months of age and found that the brain and lungs of long-lived mice contained more activity (SOD) than did those of short-lived mice. They did not find significant differences in other tissues investigated. Tolmasoff et al. (1980) and Cutler (1983) tested the hypothesis for a correlation between the expression level of SOD with maximum life span of primates (14 species, including human beings) in captivity: no general correlation was found between SOD levels and life span; however, the ratio of SOD specific activity to specific metabolic rates of the tissue or of the whole adult organism was found to augment with increasing maximum potential life span for all the species; this correlation suggests that longer-lived species have a higher degree of protection against by-products of oxygen metabolism.

Bauer (1992) analysed the variation in longevity across Europe in $M$. 
margaritifera, and he found that as temperature decreases (toward the North), the metabolic rate declines and the rate of growth decreases and this leads to a long life. According to Bauer (1992) latitude (and therefore metabolic rate) alone explained around $50 \%$ of the variation in maximum life-span (the remaining variation attributed in part to differences in hydrochemistry). Spanish populations (including those of the rivers Eo and Masma) of freshwater pearl mussel show the highest growth rates from Europe and their variation in maximum life-span is comparable to that reported for others living farther North; growth rates also showed remarkable differences (San Miguel et al., 2004) even within the same river (for example, the Eo River). Indeed, the huge variation in SOD and CAT levels found in the present study can be principally interpreted as an adaptation to the unpredictable and changing nature of freshwater natural habitats.

\section{REFERENCES}

AEBI ME (1995) Catalase. In: Bergmeyer J, Grabl BM (eds) Methods of Enzymatic Analysis vol. III. Enzymes oxidoreductases, $3^{\text {rd }}$ ed. Weinheim: Verlag-Chemie. Pp: 273-286

BANNISTER JV, BANNISTER WH, ROTILIO G (1987) Aspects of the structure, function and applications of superoxide dismutase. CRC Crit Rev Biochem 22: 111180

BARKLEY KB, GREGORY EM (1990) Tetrameric manganese superoxide dismutases from anaerobic Actinomycetes. Arch Biochem Biophys 280: 192-200

BOUZA C, CASTRO J, MARTÍNEZ P, AMARO R, FERNÁNDEZ C., ONDINA P, OUTEIRO A AND SAN MIGUEL E Threatened freshwater peral mussel Margaritifera margaritifera L. in NW Spain: low and very structured genetic variation in southern peripheral populations assessed using microsatellite markers. Conserv Genet. doi 10.1007/s10592-006-9248-0

BAUER G (1992) Variation in the life span and size of the freshwater pearl mussel. J. Animal Ecol 61: 425-436

CLAIRBONE A (1985) In Greenwald RA (ed) Handbook of methods for oxygen radical research. Florida: CRC Boca Raton. pp: 283-284

CURTSINGER JW, FUKUI HH, KHAZAELI AA, KIRSCHER A, PLETCHER SD, PROMISLOW DEL, TATAR M (1995) Genetic variation and aging. Annu Rev Genet 29: 553-575

CUTLER RG (1983) Superoxide dismutase, longevity and specific metabolic rate Gerontology 29: 113-120

DELCOURT C (1999) Las maniobras de los radicales libres. Mundo Científico 205: 81-82

ELSTNER EF, YOUNGMAN R, ObWALD W (1995) Superoxide dismutase. In Bergmeyer J, Grabl BM (eds)
Methods of Enzymatic Analysis vol. III. Enzymes oxidoreductases, $3^{\text {rd }}$ ed. Weinheim: Verlag-Chemie. pp: 293-302

FINCH CE (1994) Longevity, senescence and the genome. Chicago: Chicago University. Pp: 285-287

FRIDOVICH I (1986) Superoxide dismutases. In Meister A (ed) Advances in Enzymology and Related Areas of Molecular Biology. New York: John Wiley \& Sons. 58: 61-76

GAMBLE SC, GOLDARB PS, PORTE C, LIVINGSTONE DR (1995) Glutathione peroxidise and other antioxidant enzyme function in marine invertebrates (Mytilus edulis, Pecten maximus, Carcinus maenas and Asterias rubens). Mar Environ Res 39: 191-195

GARCÍA MARTÍNEZ P, WINSTON GW, METASHDICKEY C. O'HARA SCM, LIVINGSTONE DR (1995) Nitrofurantoin-stimulated reactive oxygen species production and genotoxicity in digestive gland microsomes and cytosol of the common mussel (Mytilus edulis L.). Toxicol Appl Pharma 131: 332-341

HARMAN D (1957) Aging: a theory based on free radical and radiation chemistry. J Gerontol 2: 298-300

HARMAN D (1962) Role of free radicals in mutation, cancer, aging, and the maintenance of life. Radiat Res 16: 753-763

HARMAN D (1981) The aging process. Proc Natl Acad Sci USA 78(11): 7124-7128

HERNÁNDEZ-NISTAL J, DOPICO B, LABRADOR E (2002) Cold and SALT stress regulates the expresión and activity of a chickpea cytosolic $\mathrm{Cu} / \mathrm{Zn}$ superoxide dismutase. Plant Sci 163: 507-514

HO Y, GARGANO M, CAO J, BRONSON R, HEIMLER I, HUTZ RJ (1998) Reduced fertility in female mice lacking copper, zinc- superoxide dismutase. J Biol Chem 273: 7765-7769

HUANG P, FENG L, OLDHAM EA, KEATING MJ, PLUNKETT W (2000) Superoxide dismutase as a target for the selective killing of cancer cells. Nature 407: 390-395

HUNT C, SIM JE, SULLIVAN SJ, FEATHRESTONE T, GOLDEN W, KAPP-HERR CU, HOCK RA, GÓMEZ RA, PARSIAN AJ, SPITZ DR (1998) Genomic instability and catalase gene amplification induced by chronic exposure to oxidative stress. Cancer Res 58: 3986-3992

KELLOGG EW 3rd, FRIDOVICH I (1976) Superoxide dismutase in the rat and mouse as a function of age and longevity. J Gerontol 31(4): 405-408

LARSEN PL (1993) Aging and resistance to oxidative damage in Caenorhabditis elegans. Proc Natl Acad Sci USA 90: 8905-8909

LEBLANC DC (2004) In Statistics. Concepts and Applications for Science. Boston: Jones and Bartlett Publishers. pp: 271-272

LIVINGSTONE DR, LIPS F, GARCÍA MARTÍNEZ P, PIPE RK (1992) Antioxidant enzymes in the digestive gland of the common mussel Mytilus edulis. Marine Biol 112: 265-276

LOWRY OH, ROSEBROUGH NJ, FARR AL, RANDALL $\mathrm{R}$ (1951) Protein measurement with the folin phenol reagent. J Biol Chem 193: 265-275

MAJIMA H, OBERLEY TD, FURUKAWA K, MATTSON MP, YEN HC, SZWEDA LI, ST CLAIR DK (1998) Prevention of mitochondrial injury by manganese superoxide dismutase reveals a primary mechanism for alkaline-induced cell death. J Biol Chem 273: 82178224

MELOV S, RAVENSCROFT J, MALIK S, GILL MS, WALKER DW, CLAYTON PE, WALLACE DC, MALFROY B, DOCTROW SR, GORDON LJ (2000) 
Extension of life-span with superoxide dismutase and catalase mimetics. Science 289: 1567-1569

MILLER JK, BRZEINSKA-SLEDOBDINSKA E, MADSEN FC (1993) Oxidative stress, antioxidants and animal function. J Dairy Sci 76: 2812-2823

ORR C, SOHAL RS (1994) Extension of life span by overexpression of superoxide dismutase and catalase in Drosophila melanogaster. Science 263: 1128-1130

PALMA JM, LONGA MA, DEL RÍO LA, ARINES J (1993) Superoxide dismutase in vesicular arbuscularmycorrhizal red clover plants. Physiol Plantarum 87: 77-83

PARKES TL, KIRBY K, PHILLIPS JP, HILLIKER AJ (1998) Transgenic analysis of the cSOD-null phenotypic syndrome in Drosophila. Genome 41: 642651

PESKIN AV (1997) Cu,Zn-superoxide dismutase gene dosage and cell resistance to oxidative stress: A review. Biosci Rep 17(1): 85-89

PESKIN AV, KOEN YM, ZBARSKY IB (1977) Superoxide dismutase and glutathione peroxidase activities in tumors. FEBS Lett 78(1): 41-45

ROSE MR (1991) Evolutionary biology of aging. New York: Oxford University Press

RUSTING RL (1998) ¿Por qué envejecemos? Investigación y Ciencia, Temas 11 (Biología del envejecimiento): 104-112

SAN MIGUEL E, MONSERRAT S, FERNÁNDEZ C, AMARO R, HERMIDA M, ONDINA P, ALTABA CR (2004) Growth models and longevity of freshwater pearl mussels (Margaritifera margaritifera) in Spain. Can J Zool 82: 1370-1379

SAS INSTITUTE Inc (1999) JMP Statistics and graphic guide. Version 3.2. SAS Insititute Inc, Cary NC
SUN J, TOWER J (1999) FLP recombinase-mediated induction of $\mathrm{Cu}, \mathrm{Zn}$-SOD transgene expression can extended the life of adult Drosophila melanogaster flies. Mol. Cell. Biol. 19: 216-228

TOLMASOFF JM, ONO T, CUTLER RG (1980) Superoxide dismutase: correlation with life-span and specific metabolic rate in primate species. Proc Natl Acad Sci USA 77: 2777-2781

VANFLETEREN JR (1993) Oxidative stress and ageing in Caenorhabditis elegans. Biochem J 292: 605-608

VIARENGO A, CANESI L, GARCÍA-MARTÍNEZ P, PETERS LD, LIVINGSTONE DR (1995) Pro-oxidant processes and antioxidant defence systems in the tissues of the Antarctic scallop (Adamussium colbecki) compared with the Mediterranean scallop (Pecten jacobaeus). Comp Biochem Physiol 111B: 119-126

WALLACE DC (1999) Mitochondrial diseases in man and mouse. Science 283: 1482-1488

WINSTON GW, LIVINGSTONE DR, LIPS F (1990) Oxygen reduction metabolism by the digestive gland of the common marine mussel, Mytilus edulis L. J Exp Zool 255: 296-308

ZIUGANOV VV, SAN MIGUEL E, NEVES RJ, LONGA A, FERNÁNDEZ C, AMARO R, BELETSKY V, POPKOVITCH E, KALIUZHIN S, JOHNSON T (2000) Life span of the freshwater pearl shell: a model species for testing longevity mechanisms in animals. Ambio 29(2): 102-105

ZIUGANOV VV, ZOTIN A, NEZLIN L, TRETIAKOV V (1994) The freshwater pearl mussels and their relationships with salmonid fish. Moscow: VNIRO Publishing House. 